\title{
Sequentially Complete Markets Remain Incomplete
}

Citation for published version (APA):

Drèze, J., \& Herings, P. J. J. (2008). Sequentially Complete Markets Remain Incomplete. Economics Letters, 100, 445-447. https://doi.org/10.1016/j.econlet.2008.03.017

Document status and date:

Published: 01/01/2008

DOI:

10.1016/j.econlet.2008.03.017

Document Version:

Publisher's PDF, also known as Version of record

Document license:

Taverne

Please check the document version of this publication:

- A submitted manuscript is the version of the article upon submission and before peer-review. There can be important differences between the submitted version and the official published version of record.

People interested in the research are advised to contact the author for the final version of the publication, or visit the DOI to the publisher's website.

- The final author version and the galley proof are versions of the publication after peer review.

- The final published version features the final layout of the paper including the volume, issue and page numbers.

Link to publication

\footnotetext{
General rights rights.

- You may freely distribute the URL identifying the publication in the public portal. please follow below link for the End User Agreement:

www.umlib.nl/taverne-license

Take down policy

If you believe that this document breaches copyright please contact us at:

repository@maastrichtuniversity.nl

providing details and we will investigate your claim.
}

Copyright and moral rights for the publications made accessible in the public portal are retained by the authors and/or other copyright owners and it is a condition of accessing publications that users recognise and abide by the legal requirements associated with these

- Users may download and print one copy of any publication from the public portal for the purpose of private study or research.

- You may not further distribute the material or use it for any profit-making activity or commercial gain

If the publication is distributed under the terms of Article $25 \mathrm{fa}$ of the Dutch Copyright Act, indicated by the "Taverne" license above, 


\title{
Sequentially complete markets remain incomplete
}

\author{
Jacques H. Drèze a ${ }^{\text {, P. Jean-Jacques Herings }}$ b,* \\ a CORE, 34 Voie du Roman Pays, B-1348 Louvain-la-Neuve, Belgium \\ b Department of Economics, Universiteit Maastricht, P.O. Box 616, 6200 MD Maastricht, The Netherlands
}

\section{A R T I C L E I N F O}

\section{Article history:}

Received 20 September 2007

Received in revised form 8 February 2008

Accepted 21 March 2008

Available online 3 April 2008

Keywords:

Sequentially complete markets

Rational expectations

Time inconsistency

JEL classification:

D52

D61

\begin{abstract}
A B S T R A C T
We show by means of an example that the result of Arrow [Arrow, K.J. (1953), Le rôle des valeurs boursières pour la répartition la meilleure des risques, Econométrie, 41-47, CNRS, Paris; translated as The role of securities in the optimal allocation of risk bearing, Review of Economic Studies, 31, 91-96] is problematic when there exist multiple equilibrium continuations to the initial-period component of an intertemporal equilibrium.
\end{abstract}

(C) 2008 Elsevier B.V. All rights reserved.

\section{Introduction}

In the standard Arrow-Debreu general equilibrium model, uncertainty is captured by an event tree, each path of which describes a potential future history of the fundamentals of the economy. This representation was introduced in Arrow (1953), where two results are presented: (i) Every efficient allocation can be sustained as a competitive equilibrium in markets for contingent claims to commodities (Theorem 1). (ii) Every efficient allocation can be sustained as a competitive equilibrium in markets for elementary securities and in spot markets for commodities (Theorem 2). An elementary security pays one unit of numeraire if and only if a specific event obtains. Markets are sequentially complete if, at each date event, there exist markets for elementary securities contingent on every immediate successor to the event.

The equilibrium concept in Radner (1972) implicitly not only imposes that price expectations are correct in the sense of being market clearing prices; it also imposes that the expected prices are the prices realized when the markets at the future date event open. Here we examine a modest weakening of that assumption. We will look for prices and price expectations that are correct in the sense of being market clearing at all date events. On top of that we will impose that

\footnotetext{
is The authors would like to thank Enrico Minelli for helpful comments and suggestions. P. Jean-Jacques Herings would like to thank the Netherlands Organisation for Scientific Research (NWO) for financial support.

* Corresponding author. Tel.: +31 43 3883824; fax: +31 433884878.

E-mail addresses: dreze@core.ucl.ac.be (J.H. Drèze), P.Herings@algec.unimaas.nl (P.J.-J. Herings).
}

the auctioneer at a future date event determines the market clearing price vector on the basis of all relevant exogenous variables (endowments and preferences). We show by means of an example that even if the competitive equilibrium is unique in an economy with sequentially complete markets, there are equilibrium continuations that are not consistent with competitive equilibrium and efficiency of the resulting allocation.

\section{An example}

Our example uses the simplest possible framework, namely a twoperiod exchange economy with two goods, two agents and no uncertainty. Markets for contingent commodities thus reduce to forward markets. Two market structures are contrasted: (1) period 0 markets for the exchange of the two spot commodities and the two forward commodities; (2) period 0 markets for the exchange of the two spot commodities and a nominal bond, followed by period 1 markets for the exchange there of the two spot commodities and the numeraire. (Our normalization plus the symmetry of the example make the numeraire equivalent to a composite commodity consisting of one unit each of the two physical commodities. Our results therefore also apply when the nominal bond is replaced by a real bond, promising the delivery of one unit of each of the two spot market commodities in period 1.) Agents are $i$ and $j$. Commodities are 01 and 02 at period 0,11 and 12 at period 1 . The endowments are $w^{i}=(2,2,0,4)$ and $w^{j}=(2,2,4,0)$. Consumption vectors are

$x^{h}=\left(x_{01}^{h}, x_{02}^{h}, x_{11}^{h}, x_{12}^{h}\right), h=i, j$. 
The preferences of $\mathrm{i}$ and $\mathrm{j}$ are represented by the following utility functions: $u^{i}=v^{i}\left(x_{01}^{i}, x_{02}^{i}\right)^{\frac{1}{2}} \cdot v^{i}\left(x_{11}^{i}, x_{12}^{i}\right)^{\frac{1}{2}}$, where

$v^{i}\left(x_{\cdot 1}^{i}, x_{\cdot 2}^{i}\right)= \begin{cases}{\left[\min \left(x_{\cdot}^{i}, x_{\cdot 2}^{i}\right)\right],} & \min \left(x_{\cdot 1}^{i}, x_{\cdot 2}^{i}\right) \leq 1, \\ {\left[\left(x_{\cdot 1}^{i}-1\right)^{\frac{1}{2}}\left(x_{\cdot 2}^{i}-1\right)^{\frac{1}{2}}+1\right],} & \min \left(x_{\cdot 1}^{i}, x_{\cdot 2}^{i}\right) \geq 1,\end{cases}$

$u^{j}=v^{j}\left(x_{01}^{j}, x_{02}^{j}\right)^{\frac{1}{2}} \cdot v^{j}\left(x_{11}^{j}, x_{12}^{j}\right)^{\frac{1}{2}}, \quad$ where

$v^{j}\left(x_{\cdot \cdot}^{j}, x_{\cdot 2}^{j}\right)= \begin{cases}{\left[\min \left(x_{\cdot 1}^{j}, x^{j}{ }_{2}\right)\right],} & \min \left(x_{\cdot 1}^{j}, x^{j}{ }_{2}\right) \leq 3, \\ {\left[\left(x_{\cdot 1}^{j}-3\right)^{\frac{1}{2}}\left(x_{\cdot 2}^{j}-3\right)^{\frac{1}{2}}+3\right],} & \min \left(x_{\cdot 1}^{j}, x_{\cdot 2}^{j}\right) \geq 3,\end{cases}$

The Edgeworth box in Fig. 1 depicts the preferences of the two agents in either period. The aggregate endowment is $(4,4)$. The initial endowment is at point Ea in period 0 , at point $\mathrm{w}$ in period 1 .

It may be verified (see Appendix A) that there exists a single competitive equilibrium on the markets at period 0 for spot and forward commodities. When we normalize prices to sum up to two, the competitive equilibrium is given by prices $p^{*}=(1 / 2,1 / 2,1 / 2,1 / 2)$ and allocation $x^{i}=\chi^{j}=(2,2,2,2)$, corresponding to point $E_{a}$ in both periods. Using equality of marginal rates of substitution and price ratios, as well as the properties of the minimum functions, it is easily verified that this is a competitive equilibrium indeed. The net trades are $z_{i}=(0,0,2,-2)$ and $z_{j}=(0,0,-2,2)$. The same allocation is sustained by no trade at period 0 in either spot commodities or the nominal bonds, followed by net trade at period $1, z_{i}^{1}=(2,-2), z_{j}^{1}=(-2,2)$, at the competitive spot prices $p_{1}^{*}=(1 / 2,1 / 2)$. That sequence defines a Radner equilibrium, the unique Radner equilibrium in this example. However - and this is the whole point of the example - there exists at period 1 another competitive equilibrium for the exchange economy with initial endowments $w^{i}=(0,4), w_{1}^{j}=(4,0)$, namely point $E_{b}$ in Fig. 1 with $z_{1}^{i}=(1,-3), z_{1}^{j}=(-1$, $3)$, and prices $\hat{p}_{1}=(3 / 4,1 / 4)$. Although the allocation $\hat{x}^{i}=(2,2,1,1), \hat{x}^{j}=$ $(2,2,3,3)$ is not sustained as an equilibrium at period 0 in spot and forward commodities, it could result from no trade in the spot-and-

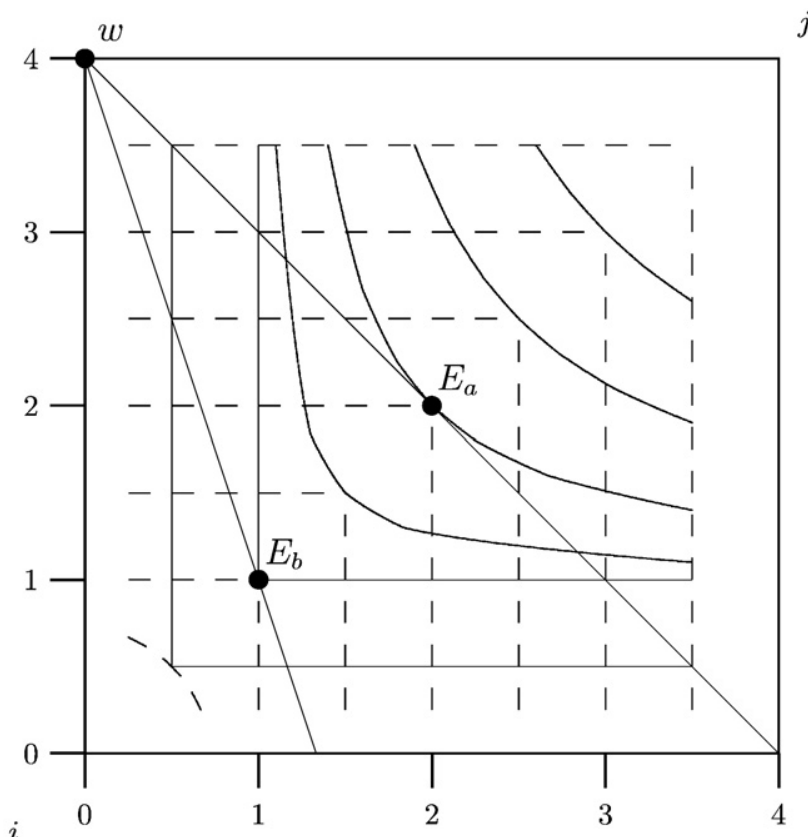

Fig. 1. Multiple equilibria at period 1. The indifference curves of $i$ are solid lines, those of $j$ are dashed. bond markets at period 0 , as specified by the Radner equilibrium, followed by the competitive equilibrium on spot markets $E_{b}$ at period 1 . Notice that this allocation is not Pareto efficient. It is Pareto dominated by the allocation $x_{\varepsilon}^{i}=(2-\varepsilon, 2-\varepsilon, 1+\varepsilon, 1+\varepsilon), x_{\varepsilon}^{j}=(2+\varepsilon, 2+\varepsilon, 3-\varepsilon, 3-\varepsilon)$, for $0<\varepsilon<1$.

\section{Comments}

1. Attention to time-inconsistent sequential equilibria is present in earlier work on incomplete markets (Hellwig (1983)) and on production economies with linear activities (Mandler (1995)) and on Sraffa's (1960) price theory (Mandler (2002)). This note shows that time-inconsistent sequential equilibria also arise in complete market pure exchange economies with unique Radner equilibria. We would like to point out that the examples presented in Kubler and Polemarchakis (2004), developed independently from our example to illustrate the non-existence of Markovian equilibria in overlapping generations models, would also qualify to show our point.

2. Our example is constructed to be simple and transparent. Preferences satisfy continuity, but not differentiability. It should be obvious that a robust example satisfying all the standard assumptions is at hand.

3. To verify the ex ante time-consistency of observed equilibria, it is not sufficient to specify only the standard primitive concepts like initial endowments, preferences, and technological constraints. Indeed, it is also necessary to specify previously held expectations concerning future prices. Moreover, the auctioneer determining the equilibrium prices at a date event, should select them in a way consistent with those expectations.

4. A simple selection mechanism is Walrasian tâtonnement, under a given starting point. In our example, using the period spot prices as starting point, equilibrium $E_{a}$ is obtained at once. However, it is easy to produce examples where unchanged prices (between periods 0 and 1 ) selects the wrong equilibrium. Suppose that

$$
\begin{aligned}
& u^{i}= v^{i}\left(x_{01}^{i}, x_{02}^{i}\right)^{\frac{1}{3}} \cdot v^{i}\left(x_{11}^{i}, x_{12}^{i}\right)^{\frac{2}{3}}, \quad \text { where } \\
& v^{i}\left(x_{01}^{i}, x_{02}^{i}\right)=\left(x_{01}^{i}\right)^{\frac{3}{4}}\left(x_{02}^{i}\right)^{\frac{1}{4}} \\
& v^{i}\left(x_{11}^{i}, x_{12}^{i}\right)= \begin{cases}{\left[\min \left(x_{11}^{i}, x_{12}^{i}\right)\right], \quad \min \left(x_{11}^{i}, x_{12}^{i}\right) \leq 1,} \\
{\left[\left(x_{11}^{i}-1\right)^{\frac{1}{2}}\left(x_{12}^{i}-1\right)^{\frac{1}{2}}+1\right],} & \min \left(x_{11}^{i}, x_{12}^{i}\right) \geq 1,\end{cases} \\
& u^{j}=v^{j}\left(x_{01}^{j}, x_{02}^{j}\right)^{\frac{3}{5}} \cdot v^{j}\left(x_{11}^{j}, x_{12}^{j}\right)^{\frac{2}{5}}, \quad \text { where } \\
& v^{j}\left(x_{01}^{j}, x_{02}^{j}\right)=\left(x_{01}^{j}\right)^{\frac{3}{4}}\left(x_{02}^{j}\right)^{\frac{1}{4}} \\
& v^{j}\left(x_{11}^{j}, x_{12}^{j}\right)=\left\{\begin{array}{l}
{\left[\min \left(x_{11}^{j}, x_{12}^{j}\right)\right],} \\
{\left[\left(x_{11}^{j}-3\right)^{\frac{1}{2}}\left(x_{12}^{j}-3\right)^{\frac{1}{2}}+3\right], \min \left(x_{11}^{j}, x_{12}^{j}\right) \leq 3,}
\end{array}\right.
\end{aligned}
$$

Consider initial endowments given by $w^{i}=(1,1,0,4)$ and $w^{j}=(3$, $3,4,0)$. One obtains a competitive equilibrium on the markets at period 0 for spot and forward commodities, with prices $p^{*}=(3 / 4$, $1 / 4,1 / 2,1 / 2)$ and allocation $x^{i}=(1,1,2,2), x^{j}=(3,3,2,2)$. The net trades are $z^{i}=(0,0,2,-2), z^{j}=(0,0,-2,2)$. The same allocation is sustained by no trade at period 0 in either spot commodities or the nominal bond, followed by net trades at period $1, z_{1}^{i}=(2,-2), z_{1}^{j}=$ $(-2,2)$ at the competitive spot prices $p_{1} *=(1 / 2,1 / 2)$. However, as before, there exists at period 1 another competitive equilibrium for the exchange economy with initial endowments $w_{1}^{i}=(0,4), w_{1}^{j}=(4$, $0)$. It is defined by the prices $\hat{p}_{1}=(3 / 4,1 / 4)$ and the net trades $z_{1}^{j}=(1$, $-3), z_{1}^{j}=(-1,3)$, resulting in the overall allocation $x^{i}=(1,1,1,1), x^{j}=$ $(3,3,3,3)$. 
That allocation is not Pareto efficient, being dominated by $x_{\varepsilon}^{i}=$ $(1-\varepsilon, 1-\varepsilon, 1+\varepsilon, 1+\varepsilon), x_{j}^{\varepsilon}=(3+\varepsilon, 3+\varepsilon, 3-\varepsilon, 3-\varepsilon)$ with $1 / 2 \geq \varepsilon>0$. In this case, sticky prices are incompatible with Pareto efficiency, which requires a change of relative prices $\hat{p}_{11} / \hat{p}_{12}$ from 3 to 1 .

5. There is no guarantee that the time-inconsistent sequence $\left(E_{a}, E_{b}\right)$ is avoided by introducing markets for forward commodities at period 0 . Indeed, in the example, agents would be indifferent between trading the forward commodities at period 0 to arrive at initial endowments $E_{a}$ at the beginning of period 1 , and not trading at all in forward commodities, but anticipating to consume $E_{a}$ by trading in the spot markets of period 1. Svensson (1976) argues that the latter option is in fact more realistic when the usually higher transaction costs involved in forward trading are taken into account.

6. The feature we exhibit is not an instance of a sunspot equilibrium. Following Gottardi and Kajii (1999), suppose there are two sunspot states in period 1, i.e. at each state the exogenous variables are identical to the ones in our example, and households commonly belief each of the states to occur with a given strictly positive probability. The bond pays off one unit of numeraire in each state. A sunspot equilibrium is then defined as a Radner equilibrium with a state-dependent allocation in period 1 . We claim that there is no sunspot equilibrium with consumption $E_{a}$ in period 0 . Indeed, when $E_{a}$ is consumed in period 0 , there is no trade in the bond, resulting in endowments of $(0,4)$ and $(4,0)$ for agents $i$ and $j$ at both states in period 1 . From then on, the only possible equilibria are $E_{a}$ and $E_{b}$. However, the anticipation of $E_{b}$ in some of the states would lead to trade in the bond in period 0 , a contradiction. We conclude that there is no sunspot equilibrium with allocation $E_{a}$ in period 0 .

7. Time-consistency of market equilibria becomes an even more relevant concern when there exists a continuum of equilibria. Examples are overlapping generations models (see Kehoe and Levine, 1985) and incomplete market models with nominal securities (see Balasko and Cass, 1989; Geanakoplos and Mas-Colell, 1989). Continua of equilibria arise also in economies with money (Drèze and Polemarchakis, 2001) or with price rigidities (Herings, 1998; Citanna et al., 2001).

\section{Appendix A}

The equilibrium defined by $p=(1 / 2,1 / 2,1 / 2,1 / 2), x^{i}=\chi^{j}=(2,2,2,2)$ is unique.

i. For $k=0,1$, if $\min \left(x_{k 1}^{i}, x_{k 2}^{i}\right) \leq 1$, Pareto efficiency requires $x_{k 1}^{j}=x_{k 2}^{j}$; if $\min \left(x_{k 1}^{i}, x_{k 2}^{i}\right) \leq 3$, Pareto efficiency requires $x_{k 1}^{i}=x_{k 2}^{i}$. But $x_{k 1}^{i}+$ $x_{k 1}^{j}=4, l=1,2$; hence, at least one of the above inequalities holds and $x_{k 1}^{i}=x_{k 2}^{i}, x_{k 1}^{j}=x_{k 2}^{j}$.

ii. It follows that $u^{i}=\left(x_{01}^{i} x_{11}^{i}\right)^{1 / 2}, u^{j}=\left(x_{01}^{j} x_{11}^{j}\right)^{1 / 2}$, so that prices supporting a Pareto efficient allocation must verify $p_{01}+p_{02}=$ $p_{11}+p_{12}$. At such prices, a competitive allocation with $x_{k 1}^{i}=x_{k 2}^{i}$, $k=1,2$, has $x_{01}^{i}=x_{02}^{i}=x_{11}^{i}=x_{12}^{i}$ and similarly for $x^{j}$.

iii. Suppose $x_{01}^{i}=1$. From budget equality for agent $i, p_{01}+p_{02}+p_{11}+$ $p_{12}=2 p_{01}+2 p_{02}+4 p_{12}$. Since $p_{01}+p_{02}=p_{11}+p_{12}$, it follows that $p_{12}=0$, which is at odds with utility maximization. Consequently, $x_{01}^{i} \neq 1$.

If $x_{01}^{i} \neq 1$, then the utility function of either agent $i$ or agent $j$ is differentiable at $x^{i}$ or $x^{j}$, respectively. From the relevant marginal rate of substitution, we obtain that $p_{01}=p_{02}=p_{11}=p_{12}$, and $x^{i}=x^{j}=(2,2,2,2)$. The net trades are $z^{i}=(0,0,2,-2)$ and $z^{j}=(0,0,-2,2)$.

\section{References}

Arrow, K.J., 1953. Le rôle des valeurs boursières pour la répartition la meilleure des risques, Econométrie, 41-47, CNRS, Paris; translated as The role of securities in the optimal allocation of risk bearing. Review of Economic Studies 31, 91-96.

Balasko, Y., Cass, D., 1989. The structure of financial equilibrium with exogenous yields: the case of incomplete markets. Econometrica 57, 135-162.

Citanna, A., Crès, H., Drèze, J., Herings, P.J.J., Villanacci, A., 2001. Continua of underemployment equilibria reflecting coordination failures, also at Walrasian prices. Journal of Mathematical Economics 36, 169-200.

Drèze, J.H., Polemarchakis, H.M., 2001. Monetary equilibria. In: Debreu, G., Neuefeind, W., Trockel, W. (Eds.), Economics Essays: A Festschrift for Werner Hildenbrand. Springer-Verlag, Heidelberg, pp. 83-108.

Geanakoplos, J.D., Mas-Colell, A., 1989. Real indeterminacy with financial assets. Journal of Economic Theory 47, 22-38.

Gottardi, P., Kajii, A., 1999. The structure of sunspot equilibria: the role of multiplicity. Review of Economic Studies 66, 713-732.

Hellwig, M.F., 1983. A note on the implementation of rational expectations equilibria. Economics Letters 11, 1-8.

Herings, P.J.J., 1998. On the existence of a continuum of constrained equilibria. Journal of Mathematical Economics 30, 257-273.

Kehoe, T., Levine, D., 1985. Comparative statics and perfect foresight in infinite horizon economies. Econometrica 48, 1211-1232.

Kubler, F., Polemarchakis, H., 2004. Stationary Markov equilibria for overlapping generations. Economic Theory 24, 623-643.

Mandler, M., 1995. Sequential indeterminacy in production economies. Journal of Economic Theory 66, 406-436.

Mandler, M., 2002. Classical and neoclassical indeterminacy on one-shot versus ongoing equilibria. Metroeconomica 53, 203-222.

Radner, R., 1972. Existence of equilibrium of plans, prices, and price expectations in a sequence of markets. Econometrica 40, 289-303.

Sraffa, P., 1960. Production of Commodities by Means of Commodities. Cambridge University Press, Cambridge (UK).

Svensson, L.E.O., 1976. Sequences of temporary equilibria, stationary point expectations and Pareto-efficiency. Journal of Economic Theory 13, 169-183. 